\title{
STORY OF SHADOW \\ KARYA KRIYA TEKSTIL DENGAN IDE INSPIRASI DARI PAPER CUT LIGHT BOX
}

\author{
Centaury Harjani \\ Centaury.h@gmail.com
}

\begin{abstract}
Abstrak
Sumber inspirasi penciptaan tidak harus dari karya-karya dengan material yang sejenis. Seperti karya kriya tekstil tidaklah harus memiliki sumber penciptaan dari karya-karya kriya tekstil sejenis yang lain. Pada tulisan kali ini akan dibahas sebuah karya kriya tekstil yang memiliki ide sumber penciptaan dari karya bermaterial kertas yaitu paper cutting. Penulisan artikel ini mengangkat teori mimesis (imitasi) Plato dan menggunakan metode eksperimen dalam melakukan uji coba pada material kain agar dapat diperlakukan seperti paper cutting pada material kertas. Artikel ini akan memberikan wawasan baru mengenai sumber ide bagaimana rasa kagum dalam pengalaman estetis dapat menginspirasi dalam mencipta sebuah karya yang memanfaatkan bayangan serta cahaya dalam perwujudannya.
\end{abstract}

Kata kunci : karya kriya tekstil, ide penciptaan, bayangan dan cahaya

\section{Pendahuluan}

Penciptaan suatu karya memerlukan ide kreatif yang khas, unik, serta berbeda. Selama ini, saat mahasiswa ingin mencipta dan mengembangkan karyanya mereka akan cenderung mencari pembanding dari jenis-jenis karya yang sejenis, untuk menemukan potensi kebaharuan yang dapat dikembangkan. Bagi penulis untuk menjadi kreatif, unik, dan berbeda memerlukan ide inspirasi dari banyak hal. Salah satu hal yang dapat dimanfaatkan sebagai sumber ide inspirasi dalam berkreasi adalah sesuatu yang dikagumi penulis. Seni Paper Cutting adalah salah satu hal yang penulis kagumi, tingginya tingkat akurasi, detail, teknik, serta hasil yang muncul begitu memukau penulis. Kreasi dengan kertas memiliki banyak varian yang begitu beragam serta kreatifitas yang seolah-olah tidak terbatas. Walaupun material kertas berbeda jika dibandingkan dengan material kain, namun dengan perlakuan tertentu material kain dapat diolah menjadi serupa dengan kertas.

Menurut Novi Rahmanita sesungguhnya pengaruh budaya asing dapat menjadi salah satu faktor yang mempengaruhi ide penciptaan suatu karya. Budaya memang dapat dijadikan sumber inspirasi namun hal lain yang dapat dijadikan sumber ide inspirasi bagi penulis dalam berkreasi adalah pengalaman akan sesuatu yang dikagumi. Karena dari hal yang dikagumi dapat terjadi proses transfer pengetahuan yang sifatnya akan mempengaruhi dan memperlengkapi penulis dalam proses penciptaan karya. Hal ini seperti yang diutarakan Mansoer dalam tulisan Novi Rahmanita bahwa “...tanpa disadari terjadi saling ambil-mengambil unsur-unsur kebudayaan masing-masing...”,yang dimaksudkan disini adalah terjadinya proses pertukaran informasi saat masuknya budaya 
luar ke Indonesia sehingga unsur budaya mempengaruhi ragam hias yang ada di Indonesia. Saat penulis mengalami rasa kagum disana penulis mengalami pengalaman estetis.

Menurut Dr. Fx. Mudji Sutrisno SJ dan Prof. Dr. Christ Verhaak SJ,

"pengalaman estetis ternyata berdasarkan pengamatan inderawi, sekaligus seluruh manusia ikut terbawaoleh pengamatan itu, jiwa raga, dengan segala indera dan kemampuan-kemampuan lainnya; bagaikan terikat dan terpikat hatinya... Bila pengalaman seperti itu sudah lewat, manusia ingin sekali lagi seakan-akan meraih kembali pengalaman yang sama itu, dengan atau juga tanpa perubahan atau variasi dibandingkan dengan yang lama”.

Dari rasa kagum yang muncul ketika mengalami pengalaman estetis, hal tersebut mendorong penulis untuk melakukan proses imitasi. Seperti yang diutarakan oleh Eva Schaper (dalam Drs.Humar Sahman, 1993) "imitation = copy (of what already there) $=$ likeness (Plato)", yaitu bahwa kegiatan imitasi adalah membuat sesuatu yang mirip dengan apa yang telah ada.

\section{Metode Penelitian}

"To 'inspire' is to stimulate creative thinking... Inspiration can be fired by interaction with materials..." (Mike Ashby dan Kara Johnson, 2010)

Merujuk pada apa yang dikatakan oleh Mike Ashby dan Kara Johnson bahwa, inspirasi yang memicu kreatifitas dapat bersumber dari interaksi dengan material maka penulis melakukan metode eksperimen dengan material kaos PE dan kain belacu dalam mengembangkan ide penciptaan karya pada artikel ini. Eksperimen dilakukan berdasarkan teori mimesis (imitasi) dari Plato untuk penulis mencari dan melakukan eksperimen pada material kain untuk diwujudkan menjadi serupa dengan karakter kertas yang dibutuhkan untuk dijadikan paper cutting light box. Pada mulanya penulis mengamati karya paper cutting light box yang berkembang,berikut salah satu karya yang dikagumi penulis.

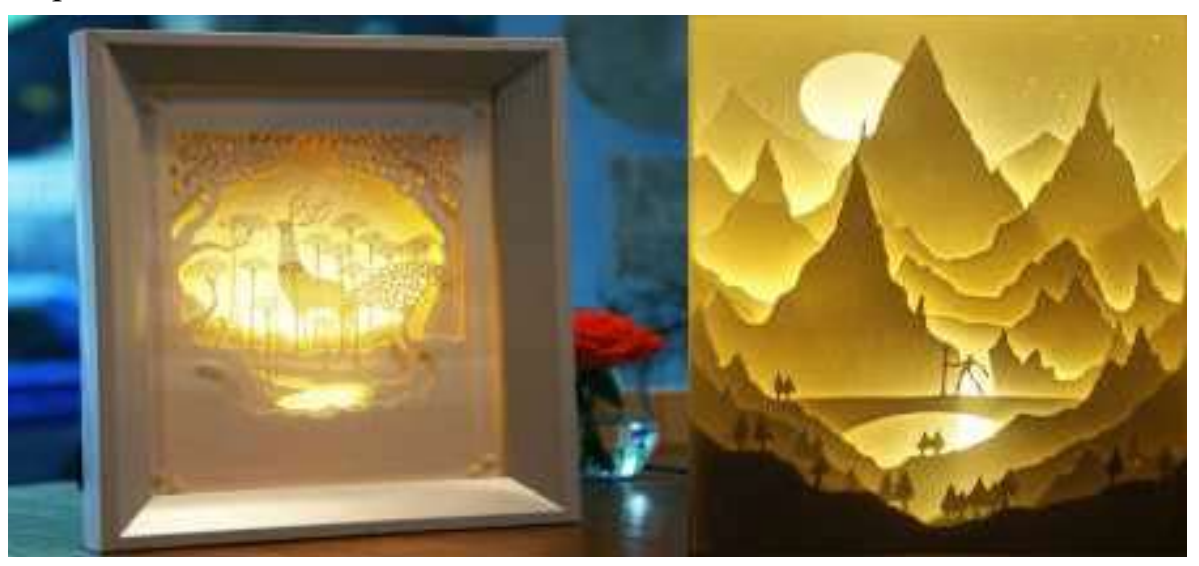

Gambar1. Foto paper cutting light box

(Sumber: diunduh dari www.designandpaper.com dan www.pinterest.com) 
Penulis mencari prinsip dan karakter dari material yang digunakan pada paper cutting light box kemudian penulis mengimitasinya untuk diwujudkan dengan material kain. Karya paper cutting light box yang diamati adalah karya Hari Panicker dan Deepti Nair. Hari adalah seorang desainer grafis dan ilustrator sedangkan Deepti adalah seorang desainer interior,mereka memulai eksperimen dengan paper cutting shadow boxes sejak 2010. Berikut contoh karya mereka yangmenjadi inspirasi penulis :
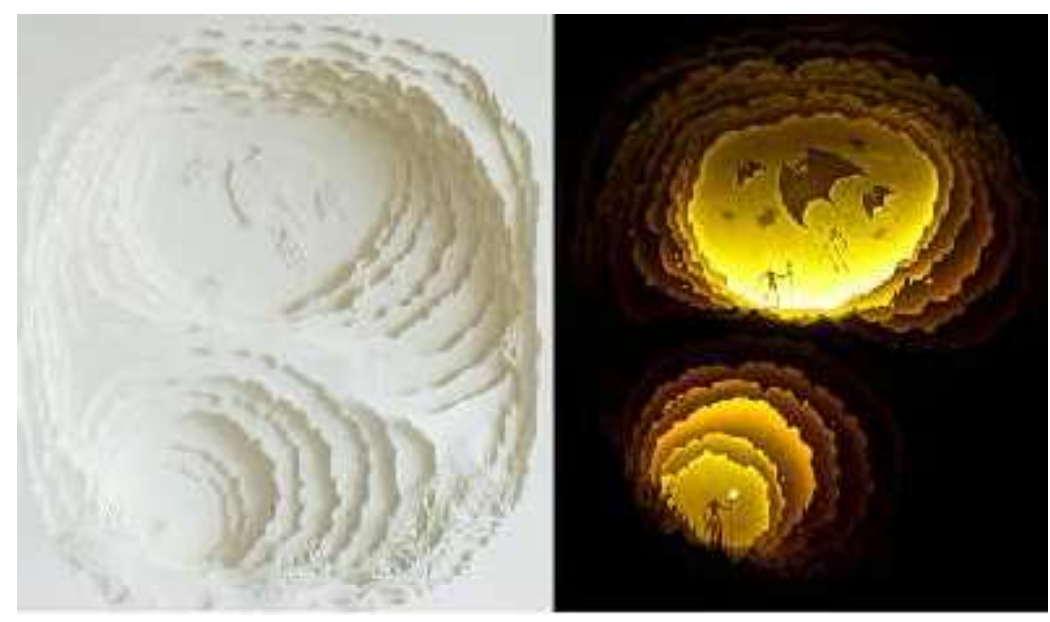

Gambar 2. Hari \& Deepti | "The World Beneath" Hand Cut Paper (Sumber: diunduh dari www.boredpanda.com)

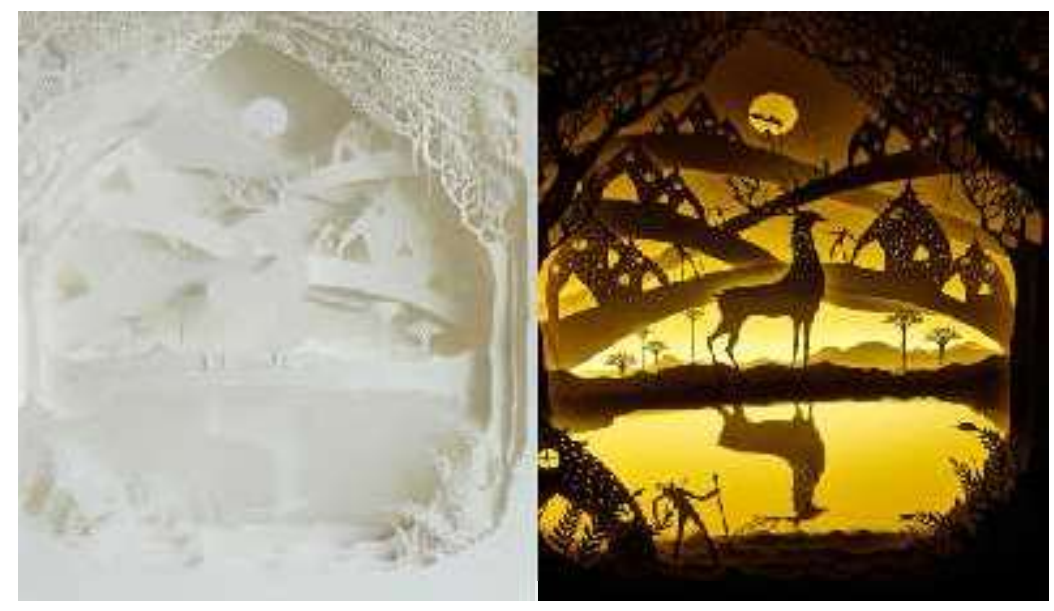

Gambar 3. Hari \& Deepti | "No Place Like..." Hand Cut Paper (Sumber: diunduh dari www.boredpanda.com) 


\section{Temuan dan Pembahasan}

Penemuan penulis dari pengamatan dan eksperimen dengan material kain untuk diwujudkan menjadi paper cutting light box adalah bahwa material kain kaos PE, belacu, dan vislin diperoleh gabungan material yang dapat diwujudkan menjadi paper cutting light box. Dimana proses perlakuannya adalah sebagai berikut :

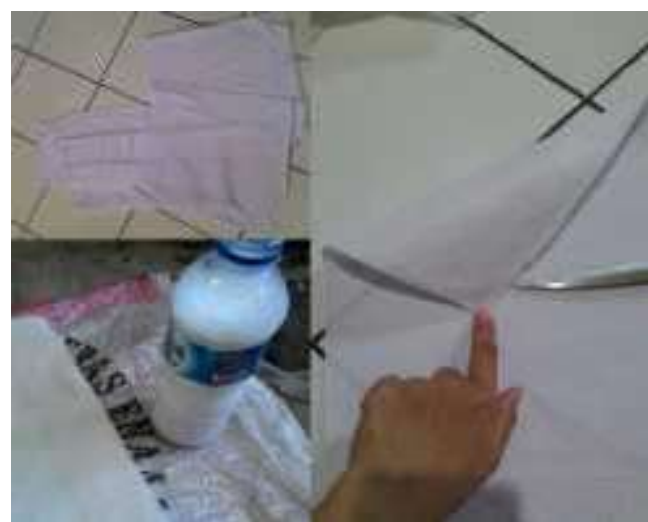

1. Kain kaos PE dipotong sesuai ukuran yang dibutuhkan $(40 \mathrm{~cm} \times 40 \mathrm{~cm})$

2. Kemudian diberi lapisan perekat dari campuran lem putih dengan air sebanyak 1:3

3. Setelah kering diperoleh kain dengan karakter yang lebih keras dan kaku.

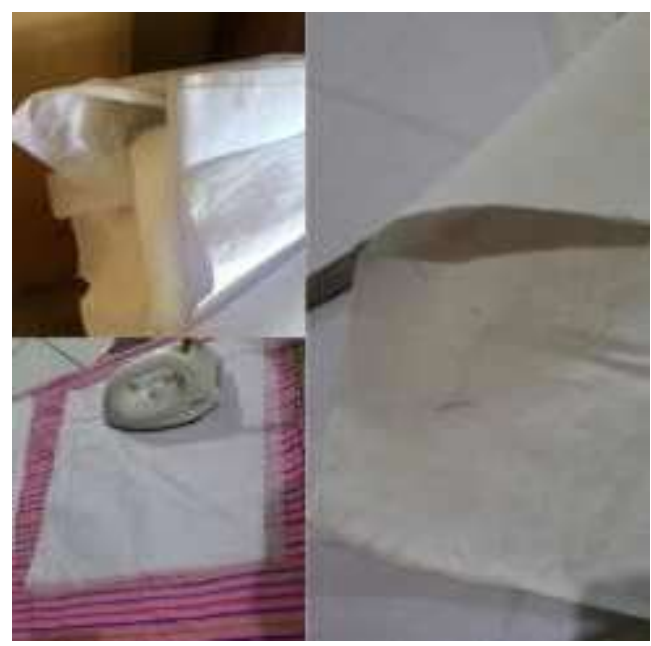

1. Kain kaos PE yang telah dilapisi digabung dengan kain keras (vislin).

2. Kain keras dipanaskan hingga merekat pada kain kaos.

3. Diperoleh karakter kain yang lebih kaku dan siap untuk diperlakukan sesuai sketsa yang diinginkan.

Setelah diperoleh karakter kain yang dibutukan, selanjutnya proses perwujudan rancangan cerita diaplikasikan pada kain, berikut tahapannya :

1. Mempersiapkan sketsa cerita

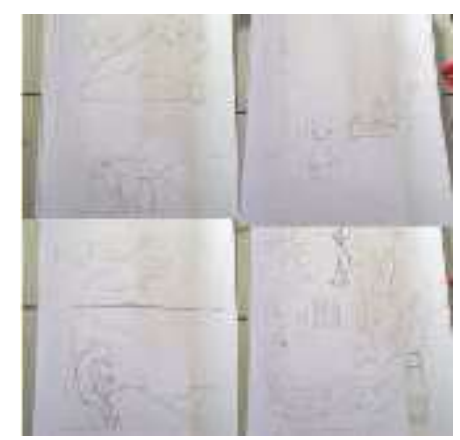


2. Memindahkan/menyalin sketsa pada kain dengan kertas karbon dan kemudian memotong kain sesuai dengan setiap pola.

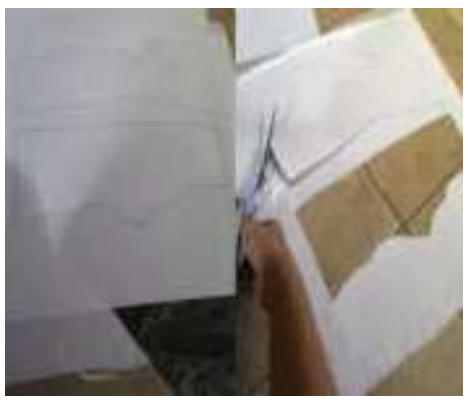

3. Contoh hasil potongan tiap pola yang telah disalin pada kain

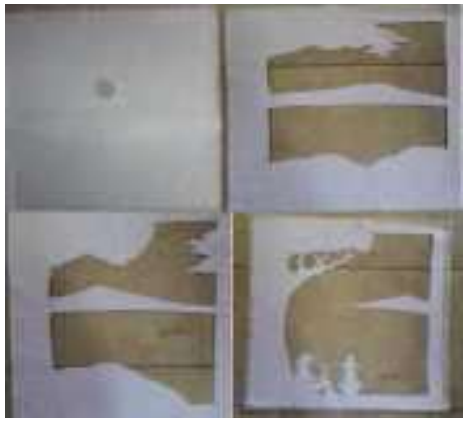

4. Menyusun tiap layering yang ada menjadi satu kesatuan

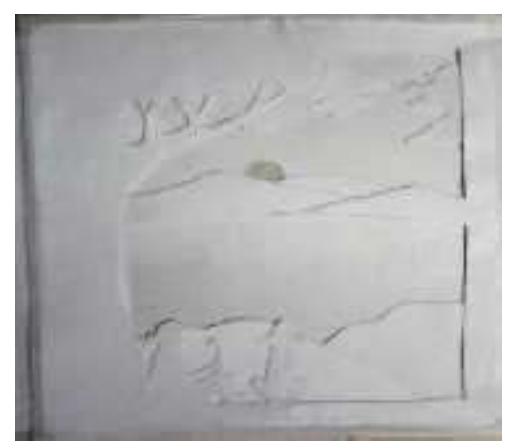

5. Memasang susunan layering kain pada box yang telah dipersiapkan dan diuji dengan cahaya lampu.

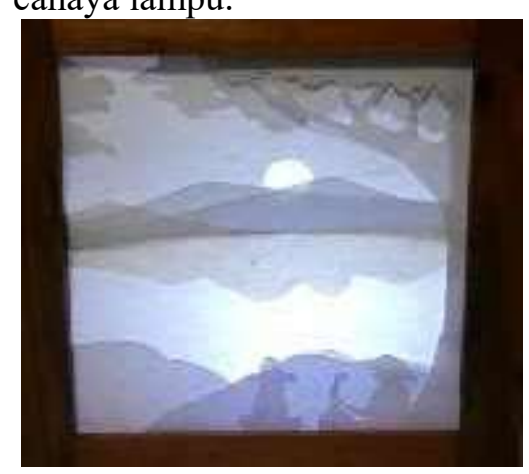


6. Menyambungkan box dengan kaki penyangga yang telah dipersiapkan.

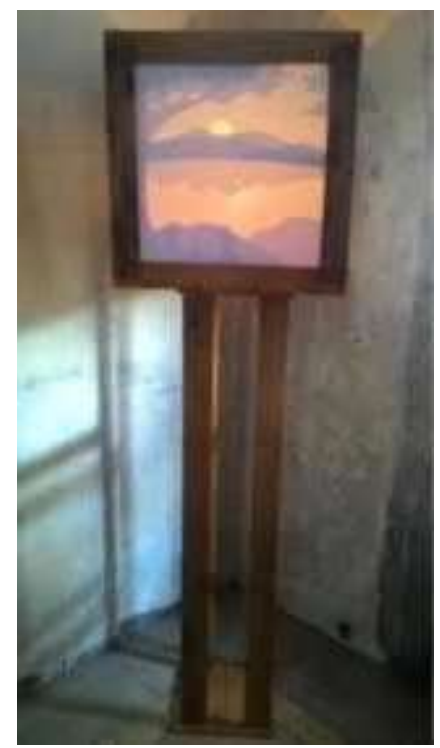

7. Langkah terakhir adalah memberi sumber pencahayaan pada box (pada gambar berikut penulis memberi sumber pencahayaaan dengan lilin)

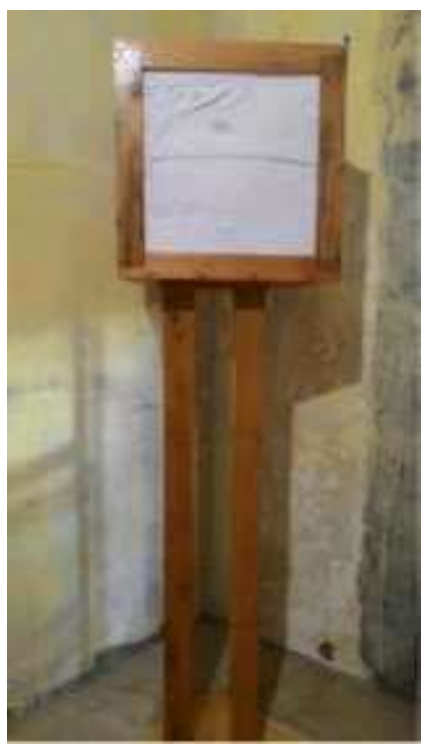

Berikut ini adalah hasil cerita yang dihasilkan dengan judul cerita "keblinger" yang mengisahkan seorang pemuda dari desa yang berhijrah ke kota hingga mendulang keberhasilan, namun di tengah keberhasilannya ia melupakan keluarganya di desa dan hidup menikmati kekuasaannya sendiri. 


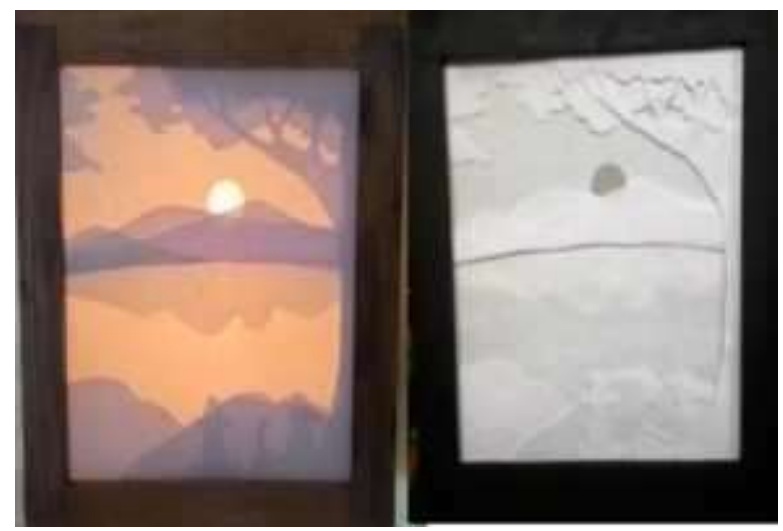

Layer1 :

Menceritakan pemuda saat masih di desa sedang akan pergi dan akan pamit pada ayahnya. Situasi pedesaan dipertegas dengan latar pemandangan pegunungan dan laut

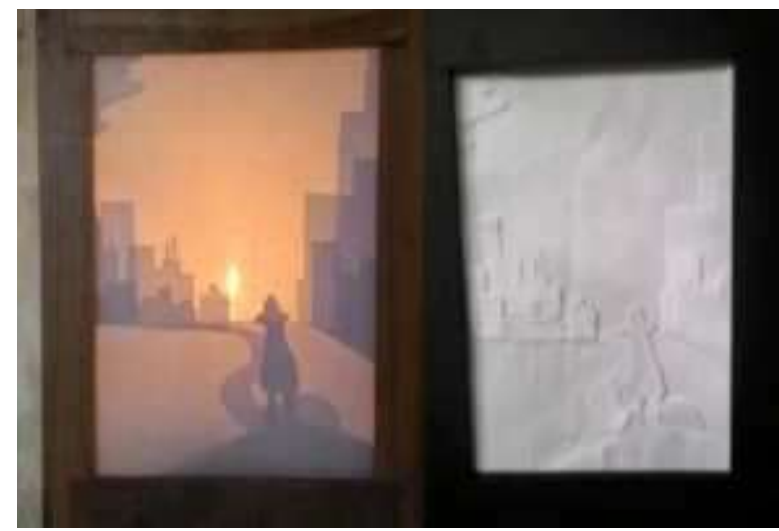

Layer2 :

Menceritakan perjalanan pemuda menuju kota besar. Suasana kota besar digambarkan dengan bangunan-bangunan bertingkat

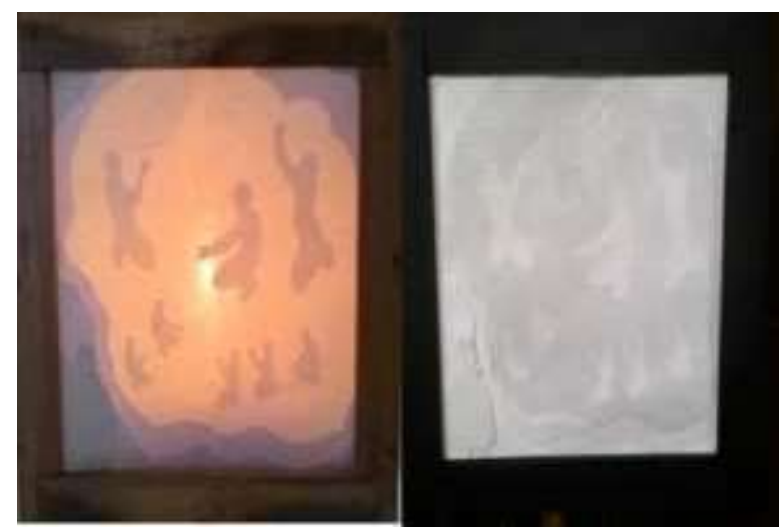

\section{Layer 3 :}

Menggambarkan pikiran pemuda yang mulai terobsesi dengan kekuasaan. Keinginan tersebut digambarkan dengan siluet banyak orang yang sedang bersujud memohon dan menyembah

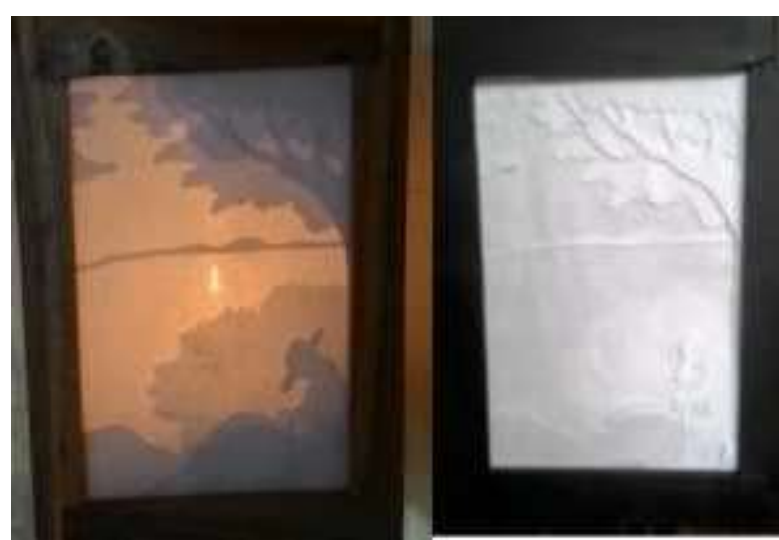

Layer 4:

Menceritakan ayah sang pemuda di desa sedang tertunduk sedih, karena sang pemuda tidak memberi kabar atau pun menjenguk sang ayah 


\section{Kesimpulan}

Sumber inspirasi penciptaan dapat bersumber darimana saja termasuk dari material yang berbeda. Pengalaman estetis yang didapat saat merasakan kekaguman kemudian dikembangkan bersama dengan pengamatan inderawi dapat memicu kreatifitas dalam perwujudan karya.

\section{KEPUSTAKAAN}

Ashby, Mike dan Kara Johnson. 2010. "Materials and Design: The Art and Science of Material Selection in Product Design". Canada: Elsevier Ltd.

Mansoer,dkk. 1970. "Sejarah Minangkabau”. Jakarta: Bharata.

Rahmanita, Novi. 2012. "Pengaruh Kebudayaan Asing Dalam Pembentukan Ragam Hias Pelaminan". Corak Jurnal Seni Kriya Vol.1(No.2), 143-149.

Sahman, Humar. 1993. "Estetika: Telaah Sistemik dan Historik". Semarang: IKIP Press. Sutrisno SJ, Fx.Mudji dan Christ Verhaak SJ. 1993. "Estetika: Filsafat Keindahan". Yogyakarta: Penerbit Kanisius.

http://www.boredpanda.com/illuminated-paper-sculptures-shadow-art-hari-deepti/ https://www.designandpaper.com/?p=6288

https://www.pinterest.com/source/blackbookgallery.com 